\title{
AGRICULTURE IN THE FUNCTION OF RURAL DEVELOPMENT - CASE STUDY FROM REPUBLIC OF SERBIA AND REPUBLIC OF SRPSKA
}

\author{
Mirjana Delić Jović, Tamara Gajić2 ${ }^{2}$, Biljana Rađenović Kozić3 \\ *Corresponding author E-mail: tamara.gajic.1977@gmail.com
}

A R T I C L E I N F O
Review Article
Received: 07 February 2021
Accepted: 03 June 2021
doi:10.5937/ekoPolj2102463D
UDC 338.43:711.3(497.11)
(497.6 Republika Srpska)

Keywords:

agriculture, rural development, Republic of Srpska, Republic of Serbia

JEL: Q10, R14

\begin{abstract}
A B S T R A C T
Rural areas in Republic of Serbia and Republic of Srpska, but also in the surrounding countries, are rich in natural resources suitable for agricultural and rural development. The authors of the paper performed a comparative analysis of agricultural development and the possibility of influencing rural development in Serbia and Republic of Srpska. In addition to the available secondary documentation, they used data from FAOSTAT (Food and Agriculture Organization of the United Nations). The authors conducted a survey in the rural areas of the two countries during 2019, on a total sample of 215 respondents, farm owners. The obtained data were analyzed in the SPSS software, version 23.00. The descriptive statistical analysis gave an insight into the shortcomings of agricultural development, while the paired samples t-test confirmed the hypothesis of the existence of a statistically significant difference in certain categories.
\end{abstract}

(C) 2021 EA. All rights reserved.

\section{Introduction}

The modern definition of the term rural development implies integral and multisectoral and sustainable development. The integral development of rural areas is important due to the diversification of the rural economy, which in the time of modern structural processes and events faces numerous problems such as depopulation, population aging,

1 Mirjana Delić Jović, Ph.D., Dean, University of Business Studies, Jovana Dučića 23a, Banja Luka. Phone: + 38765984 818, E-mail: mdelicjovic@yahoo.com, ORCID ID (https:// orcid.org/0000-0003-1707-8742)

2 Tamara Gajić, Ph.D., Associate professor, Faculty of Tourism and Hotel Management, Singidunum University, Danijelova 32, Belgrade, Senior Researcher, Department of the Tourism and Socio-Cultural Service at the Institute of Sport, Tourism and Service, South Ural State University, Chelyabinsk, Russia. Phone: + 38163565 544, E-mail: tamara. gajic.1977@gmail.com, ORCID ID (https://orcid.org/0000-003-3016-8368)

3 Biljana Rađenović Kozić, Ph.D., Dean, Faculty of Applied Economics, University of Business Studies, Jovana Dučića 23a Banja Luka, Phone: + 38765662 470, E-mail: biljanarkozic@gmail.com, ORCID ID (https://orcid.org/0000-0001-7781-3120) 
landscape fossilization, and generally deteriorating socio-economic indicators that make this area passive and undesirable (Stewart et al., 2006; Boyd, 2008; Andrei et al., 2017). Traditionally, rural areas are associated with the use of natural resources and the economic branches of agriculture and forestry. However, in the development of rural areas in modern times, the importance of education, economic development and infrastructure development has been recognized. There are 6,158 settlements on the territory of Republic of Serbia, of which 193 belong to urban (3.1\%), and 5,965 are other settlements, which are automatically considered rural (Cvijanović et al., 2020a; 2020b). In the period 2002-2011. year, the total number of inhabitants decreased by $4.15 \%$, which is primarily a consequence of the negative natural increase and going abroad (Cvijanović et al., 2012; Gajić et al., 2020). In this period, the rural population decreased by 311,139 inhabitants $(10.9 \%)$, ie it dropped to a level below three million, and today it makes up $40.6 \%$ of the total population of Republic of Serbia. In Serbia today, agriculture provides about $12 \%$ of the gross value added of the economy, and the agricultural population, according to the 2002 census, makes up about $11 \%$ of the total population (Njegovan et al., 2009).

Agricultural land in Republic of Srpska covers about 5.3 million hectares. The area of used agricultural land is about 3.4 million hectares, with arable land and gardens dominating with $76 \%$, permanent grasslands occupying $18 \%$, and permanent plantations about 6\% (Cvijanović et al., 2012; 2020a). Agricultural production, as a basic feature of rural development, in relation to its contribution to GDP, is a very important branch of production for the Republic of Srpska. Of all the manufacturing sectors, agriculture has the largest share in the structure of GDP (larger than the manufacturing industry). However, the gross value added of agriculture is declining both in absolute and relative terms, mainly due to the faster development of other sectors of the economy. Agriculture sector in the period 2007-2013 participated in the total GDP of Republic of Srpska with 9-11\%. In the period 2007-2013 year, a total of about 550 million KM $(\mathrm{KM} 1=€ 0.5118)$ was allocated from the agrarian budget, ie about 78 million KM, on an annual level. In the Republic of Srpska, $45.48 \%$ of the total arable land is not cultivated. According to the results of the 2013 census, there are 131,586 agricultural farms in Republic of Srpska (Gajic et al., 2018). In the register of agricultural holdings of the Ministry of Agriculture, Forestry and Water Management of the Republic of Srpska, there were 65,458 registered holdings (about $50 \%$ of the total number of agricultural holdings), among which the vast majority of farms produced exclusively for their own needs (Parausić et al. 2007; Bogdanov, 2007; Bakić, 2020).

At the beginning of the observed period, rural development policy was more significantly represented in the total budget expenditures for agricultural support (Anriquez et al., 2007; Jasur et al., 2016). The largest share in the support of rural development has funds intended for incentives for capital investments on agricultural holdings. Investments on the agricultural farm were encouraged by non-refundable funds for the renovation and construction of facilities, procurement of equipment and machinery, renovation and expansion of perennial plantations. The European policy for the development of 
rural areas is based on the principle of decentralization of responsibilities, whereby it is necessary to strengthen partnerships and the inflow of investments into the poor parts of the member states (De Haan et al, 2005; Varin et al., 2016; Done et al, 2012). The prime reason that underlay the establishing and strengthening of the European Union (EU) was to provide the requisite framework for the permanent improvement of the living standard of its citizens (Chivu et al,2015; Nica et al., 2018). The European Commission has prescribed 22 measures that must be fulfilled and which are obligatory for all member states. Current rural development policy for the period 2014-2020 it has retained many previous policy measures with an emphasis on long-term strategic goals, while fostering competitiveness in agriculture, emphasizing the fight against climate change with nature protection, and improving rural areas through strategies to increase employment (Arce, 2003; Cvijanović et al., 2020b). Activities related to increasing the volume of agricultural production of a country are usually expressed through rural development programs and projects. However, although agriculture is rightly the most important goal in rural development, rural development should also include non-agricultural aspects of rural life (Jasur et al., 2015; Varun et al., 2016). The concept of rural development must be considered with special reference to agriculture, because agriculture is the basis for the life of most families in rural areas. In the last two decades, there has been an increasing emphasis on rural development programs and projects and the recognition that the development of rural areas is just as important as the construction of urban, industrial complexes. Development must have two pillars: urban industrialization and the improvement of rural areas (Arce, 2003; Smith, 2006; Shiru, 2008).

Labor has wider social, economic and economic significance. There is still an insufficient amount of research on this issue. The research came to certain conclusions related to the current state of agricultural and rural development of the given countries and countries in the region. The research included 215 respondents from farm owners, and based on their answers, key problems that slow down agricultural and rural development can be identified, and based on that, key strategic measures for improving production and the entire economy can be adopted. The authors of the paper in the software SPSS 23.00, showed a descriptive statistical analysis of the situation, ie the attitude of respondents on the main shortcomings of agricultural and rural development. While using the paired sample t-test, it was found that there is a statistically significant difference between certain categories between the two observed states.

\section{Literature review}

Diversification of the rural economy is crucial because it is a prerequisite for demographic stabilization, which is the basis for the sustainability of all components of development. Rural development is the process of improving the quality of life and economic well-being of people living in rural areas (Pradhan, 2015; Gajić et al., 2017). Rural development activities aim at the socio-economic development of rural areas, with the direct participation of the rural population in order to meet the needs specific to the area and to provide a socio-economic and cultural framework. Unlike urban areas, rural 
areas are extremely different from each other in terms of natural and cultural heritage, so it is necessary to develop local, regional and national rural development programs that are tailored to the area (Atanassoaie, 2011; Varin et al., 2016; Gajić et al., 2020). When thinking about rural development, one must take into account the whole range of problems that the farmer faces on a daily basis. Some of these problems will be physical or tangible and relatively easy to recognize. Many of these problems stem from the place of farmers in the social and political structure in rural areas. Farmers and their families are involved in a complex network of relationships with other farmers in the area and often these relationships bring problems (Wetterstrand, 2019). Farmers may also have little access to the resources necessary for development. Finally, they may have had very little contact with rural development programs or other state and local co-financing of this branch of the economy and may not have known how to take advantage of such activities (Broad, 2006; Ogifeda, 2010). There are very strong reasons why resources should now be invested in rural development. More than half of the world's people and the vast majority of people in developing countries (Asia, Africa and Latin America) live in rural areas and earn part or all of their income from some form of agriculture (Pillay et al., 2013). Most of these people are still very poor and dependent on agricultural practices that have made little use of modern technology. They live in isolated and often inhospitable places, with little access to the resources they need to improve agriculture. Only in terms of the number of people, there is a very strong argument for giving high priority to rural development (Hecht et al., 2019; Scott, 2020).

The specifics of agricultural production are: that it significantly depends on natural soil conditions, relief, soil configuration, climate, new technologies, etc., which leads to greater or lesser fluctuations in annual production, greater business risk and income instability of agricultural producers; agriculture participates in the formation of national income and is the main source of accumulation for the development of industry (Pender, 2004). With the beginning of industrialization, agriculture was neglected, that its share decreases along with the development of non-agricultural activities, especially industry. The importance of agriculture is a strategic determinant of the EU economy (Baguedano et al., 2011). Food and beverage production in the EU generates 14.9\% of the total revenue of the processing industry, and employs 4.5 million employees (Cvijanović et al., 2020a). Agriculture as an activity is an extremely important economic and social dimension of the economy of the surrounding countries (Gajić et al., 2017). In Croatia and Serbia, agricultural production, the state of rural development and demographic trends record the same heritage, similar negative macroeconomic development trends, and negative demographic trends in rural areas (Folke, 2002). 
Table 1. Basic production indicators (analysis of areas under crops in thousands of hectares).

\begin{tabular}{|l|c|c|c|c|c|c|c|c|c|c|c|c|}
\hline & \multicolumn{3}{|c|}{ Bosnia and Hercegovina } & \multicolumn{4}{|c|}{ Serbia } & \multicolumn{3}{c|}{ Croatia } & \multicolumn{3}{c|}{ Slovenia } \\
\hline & $\mathbf{2 0 0 5}$ & $\mathbf{2 0 1 2}$ & $\mathbf{2 0 1 9}$ & $\mathbf{2 0 0 5}$ & $\mathbf{2 0 1 2}$ & $\mathbf{2 0 1 9}$ & $\mathbf{2 0 0 5}$ & $\mathbf{2 0 1 2 .}$ & $\mathbf{2 0 1 9 .}$ & $\mathbf{2 0 0 5 .}$ & $\mathbf{2 0 1 2 .}$ & $\mathbf{2 0 1 9 .}$ \\
\hline Apple & 14.309 & 15.027 & 30.934 & 24.000 & 24.400 & 26.089 & 5.625 & 5.980 & 4.950 & 3.099 & 2.702 & .2270 \\
\hline Barley & 19.644 & 20.453 & 20.908 & 93.520 & 80.803 & 100.118 & 50.341 & 56.905 & 53.660 & 1.5451 & 17.967 & 21.140 \\
\hline Beans & 9.499 & 8.955 & 6.991 & 22.678 & 12.906 & 9.091 & 6.477 & 788 & - & 451 & 289 & - \\
\hline Grapes & 5.200 & 5.600 & 4.353 & 62.151 & 36.020 & 20.501 & 29.670 & 29.237 & 19.820 & 16.428 & 16.351 & 15.570 \\
\hline Maize & 196.372 & 196.504 & 191.540 & 1.169. & 976.020 & 962.083 & 318.973 & 299.161 & 255.890 & 42.369 & 39.166 & 38.880 \\
\hline Oats & 16.830 & 10.280 & 10.208 & 42.530 & 34.554 & 22.669 & 21.185 & 28.514 & 18.500 & 2.731 & 1.369 & 1.210 \\
\hline Potatoes & 41.352 & 36.787 & 34.239 & 84.434 & 52.035 & 34.110 & 18.903 & 10.232 & 9.390 & 6.306 & 3.386 & 2.800 \\
\hline Rye & 3.265 & 3.456 & .3561 & 6.855 & 4.375 & 5.046 & 1.848 & 846 & 1.580 & 1.320 & 902 & 1.180 \\
\hline Soya & 5.510 & 5.325 & 9.026 & 156.680 & 162.714 & 229.372 & 48.211 & 54.109 & 78.330 & 172 & 140 & 1.430 \\
\hline Tomatoes & 4.048 & 3.714 & 3.464 & 2.0947 & 9.158 & 7.888 & 659 & 448 & 320 & 164 & 221 & 220 \\
\hline Wheat & 81.239 & 60.713 & 68.965 & 53.9813 & 603.275 & 2.399 .225 & 146.253 & 186.949 & 143.150 & 30.059 & 34.586 & 26.730 \\
\hline
\end{tabular}

Source: FAOSTAT (Food and Agriculture Organization of the United Nations), 2018.

Table 2. Basic production indicators (crops in tons)

\begin{tabular}{|l|l|l|l|l|l|l|l|l|l|l|l|l|}
\hline & \multicolumn{3}{|c|}{ Bosnia and Hercegovina } & \multicolumn{3}{|c|}{ Serbia } & \multicolumn{3}{c|}{ Croatia } & \multicolumn{3}{c|}{ Slovenia } \\
\hline & $\mathbf{2 0 0 5 .}$ & $\mathbf{2 0 1 2 .}$ & $\mathbf{2 0 1 9}$ & $\mathbf{2 0 0 5 .}$ & $\mathbf{2 0 1 2}$ & $\mathbf{2 0 1 9}$ & $\mathbf{2 0 0 5 .}$ & $\mathbf{2 0 1 2 .}$ & $\mathbf{2 0 1 9 .}$ & $\mathbf{2 0 0 5 .}$ & $\mathbf{2 0 1 2 .}$ & $\mathbf{2 0 1 9 .}$ \\
\hline Apple & 52.181 & 50.023 & 98.265 & 240.320 & 243.987 & 499.578 & 57.298 & 3.7414 & 68.350 & 106190 & 55360 & 54270 \\
\hline Barley & 51.879 & 65.337 & 7.4462 & 275.640 & 278.367 & 373.340 & 162.530 & 235.778 & 278.660 & 61.239 & 84727 & 102480 \\
\hline Beans & 13.461 & 9.395 & 11.114 & 44.338 & 10.428 & .9027 & 6.041 & 472 & - & 959 & 380 & - \\
\hline Grapes & 23.273 & 2.5931 & 32.289 & 359.454 & 263.419 & 163.516 & 181.021 & 187.550 & 108.300 & 120868 & 92324 & 105200 \\
\hline Maize & 1.004 .099 & 539.432 & 1.235 .596 & 6016765 & 3532602 & 7344542 & 2206729 & 1297590 & 2298320 & 351168 & 277358 & 360360 \\
\hline Oats & 37.946 & 26.816 & 27.231 & 84.439 & 77.262 & 56.242 & 49.470 & 94.542 & 58.250 & 7.629 & 4.351 & 4.030 \\
\hline Potatoes & 458.615 & 299.935 & 381.308 & 930.305 & 577.966 & 702.086 & 273.409 & 151.278 & 173.150 & 144714 & 79.253 & 65.960 \\
\hline Rye & 7.516 & 10.748 & 10.449 & 15.417 & 10.640 & 12.963 & 4.737 & 2.426 & 6.990 & 4.092 & 3.422 & 4.480 \\
\hline Soya & 12.482 & 6.708 & 23.753 & 429.639 & 280.638 & 700.502 & 119.602 & 96.718 & 244.280 & 333 & 343 & 4.240 \\
\hline Tomatoes & 30.738 & 44.029 & 43.700 & 189.222 & 155.663 & 111.639 & 18.731 & 22.020 & 146.253 & 6.629 & 7.313 & 9.010 \\
\hline Wheat & 248.332 & 225.137 & 264.769 & 1875335 & 2399225 & 2534643 & 601.748 & 999.681 & 803.270 & 141293 & 188065 & 139810 \\
\hline
\end{tabular}

Source: FAOSTAT (Food and Agriculture Organization of the United Nations), 2018.

According to the statistical data of FAOSTAT (Food and Agriculture Organization of the United Nations, 2018), there are a total of 2,210 thousand hectares of agricultural land in Bosnia and Herzegovina.About 1,484 thousand hectares in Croatia, 3,464 thousand hectares in Serbia, and 612 thousand hectares of agricultural land in Slovenia. Agriculture, measured by its contribution to the creation of gross domestic product (GDP), is very important for Serbia and Republika Srpska. In the European Union, the common market includes both agricultural production and trade in agricultural products (Cvijanović et al., 2012). Agricultural trade represents in the functional and highly competitive contemporary economies a viable tool in the process of valuing the national agricultural potential (Andrei et al, 2020). The objectives of the EU's common agricultural policy are: to increase agricultural productivity by advancing technical development; rationalization of agricultural production and optimal use of factors of production, especially labor; ensuring in this way an adequate standard of living for the 
agricultural population, in particular by increasing the wages of agricultural employees; market stabilization, guaranteeing supply, ensuring supply of consumers at reasonable prices (Lemos, 2007; Winder, 2019). The importance and role of agriculture came to the fore especially during the sanctions of the $1990 \mathrm{~s}$, when agriculture proved to be the most vital economic sector. Today's state of agriculture in the Republic of Serbia, its potentials and limitations, still show the same trend - to invest less in agriculture than it needs and, accordingly, to get less from it than possible (Gajić et al., 2017; Domanović et al., 2018). While in the last decade of the last century and the first half of the first decade of the XXI century, a constant foreign trade deficit was recorded (except for the symbolic surplus in 2000), and in recent years a significant surplus has been recorded (Bogdanov, 2007; Triveli et al., 2019). But despite that, production and processing, viewed as a whole, are still at a very low level of profitability and the necessary standards in the field of food safety, for its products to be sufficiently competitive and sought after in demanding markets, primarily the European Union market (Robert, 2001). Since the mid-1990s, the predominant source of investment in agriculture has been the agrarian budget, which in the period from 2001 to 2012 recorded significant oscillations, with a tendency to decrease, in recent years (Gajić et al., 2017). Short-term and long-term measures and actions are needed in order to stop the negative trends and activate the potentials of this strategic economic branch of the Republic of Serbia (Gajić et al., 2017). Production volume: Problems inherited from the previous period, as well as new challenges, problems and omissions in the transition process, have made agriculture achieve a much slower growth of production compared to the possibilities for many years (Scoones, 2007; Quevedo-Leon et al., 2019).

\section{Methodlogy}

In accordance with the defined problem area of work, and in order to test the initial hypothesis, qualitative and quantitative research methodology was used to present the key indicators of agricultural development. The authors processed the obtained results in the software SPSS 23.00, and based on descriptive statistical analysis obtained average estimates and values of standard deviation for the examined variables. The total sample consisted of 215 respondents, of which 107 respondents from Republic of Srpska and 108 from Republic of Serbia, and all are from the category of owners of agricultural holdings or registered agricultural producers. Only those questionnaires that provided complete answers to all questions were considered. A t-test for dependent samples was used to compare the mean values of the results and determine the statistical significance of their differences. The main goal is to determine whether there is a statistically significant difference between the average values of the determined variables for both countries. The term "statistically significant differences" has a very definite and defined meaning in statistics. If we claim that a difference is statistically significant, then we have determined that this difference, regardless of size, is not accidental, but that it very likely exists. When applying statistical tests, a significance level of 0.05 is generally used, that is, the probability that the hypothesis is set is wrong is less than 5\%. The purpose of the application of secondary documentation is to determine the factors that influenced the development of agriculture in the earlier 
development phases, because it is important for determining their future directions of development. The initial research hypotheses were also determined:

H1: there is no statistically significant difference between certain categories of agricultural development between Republic of Serbia and Republic of Srpska.

Hla: there is a statistically significant difference between certain categories of agricultural development between Republic of Serbia and Republic of Srpska.

H2: Agricultural production is a key factor in rural development

\section{Results and Discussions}

Categorical variables (features) are shown by relative (\%) frequency. The central tendency of numerical variables (features) is shown by the arithmetic mean (m), and the scattering by the standard deviation (sd). The frequency distribution of numerical features was examined by indicators of skewness and kurtosis. Since all variables are normally distributed, parametric statistics methods were used. The $\mathrm{t}$ - pair test was used to examine the differences, and the Pearson correlation coefficient (r) was also shown. The selected significance level is $\mathrm{p}<0.05$. The results are shown in a tables. Generally speaking, the instrument shows satisfactory measuring characteristics. Reliability was determined by the Crombach alpha coefficient. The internal reliability of the questionnaire used is over 0.80 (Krombach's alpha coefficient $\alpha=0.867$, with standardization $\alpha=0.863$ ).

Table 3. Descriptive item analysis for Republic of Serbia and Republic of Srpska (average grades and standard deviation)

\begin{tabular}{|l|c|c|}
\hline \multicolumn{1}{|c|}{ Datas for Republic of Serbia } & $\mathrm{m}$ & $\mathrm{sd}$ \\
\hline 1. Lack of advisory bodies & 1,89 & 0,868 \\
\hline 2. Salles and collection of products & 1,75 & 0,810 \\
\hline 3. Administrative barriers and efficiency of local public administration & 1,60 & 0,791 \\
\hline 4. Underdeveloped rural infrastructure & 1,60 & 0,795 \\
\hline 5. Creating a brand of agricultural products & 1,53 & 0,784 \\
\hline 6. Provision of quality standards & 1,79 & 0,902 \\
\hline 7. Knowledge transfer & 1,51 & 0,790 \\
\hline 8. Developing cooperatives and associations & 1,70 & 0,835 \\
\hline 9. Improving competitiveness with sustainable development investments & 1,62 & 0,804 \\
\hline 10. Supports for youth & 1,53 & 0,689 \\
\hline \multicolumn{1}{|c|}{$\mathrm{sd}$} & \\
\hline 1. Lack of advisory bodies & & \\
\hline 2. Sales and collection of products & 1,55 & 0,645 \\
\hline 3. Administrative barriers and efficiency of local public administration & 1,59 & 0,780 \\
\hline 4. Underdeveloped rural infrastructure & 1,48 & 0,748 \\
\hline 5. Creating a brand of agricultural products & 1,33 & 0,681 \\
\hline 6. Provision of quality standards & 1,53 & 0,796 \\
\hline 7. Knowledge transfer & 1,53 & 0,784 \\
\hline 8. Developing cooperatives and associations & 1,79 & 0,902 \\
\hline 9. Improving competitiveness with sustainable development investments & 1,51 & 0,790 \\
\hline 10. Supports for youth & 1,70 & 0,835 \\
\hline
\end{tabular}

*arithmetic means, $\mathrm{sd}=$ standard deviation 
Table 3. provides insight into the descriptive values of the issues for both countries. The lack of advisory bodies in Serbia was assessed with an average score of $\mathrm{m}=1.89$ $(\mathrm{sd}=0.868)$. When observing the value of the same item for the Republic of Srpska, the average score is approximately $\mathrm{m}=1.55$. Which indicates a lower level of activity of advisory bodies in the development of agricultural production, as well as the overall rural development. Various associations and organizations of agricultural producers are a basic component of this way of organizing agricultural advice. In Great Britain, Australia and other countries around the world, where there is a way of organizing agricultural advice, research institutions and experimental stations are under the jurisdiction of the state (Hecht et a., 2019). The arithmetic value for the issue of sales and collection of products, but also services for Republic of Serbia is $m=1.75$, while for the Republic of Srpska $m=1.599$. Which indicates that the respondents in Serbia are more satisfied with the sale and collection of agricultural products and in general the foreign trade exchange of the mentioned products. That there are administrative barriers is shown by the research data in both countries: the score for this item in Serbia is $\mathrm{m}=1.60(\mathrm{sds}=0.791)$, while for Republic of Srpska $\mathrm{m}=1.48(\mathrm{sd}=0.748)$. The adoption of the new Ordinance, which refers to the sale of small quantities of agricultural products, made it possible for products to be sold to end consumers without special procedures (Cvijanović et al., 2020). These are traditional products that, while respecting the principles of food safety, can be sold on markets, retail outlets, but also on the farm itself. The Ordinance stipulates that raw milk, eggs, cheese, fish and game may be sold in this way, but only in the quantities provided for in the Ordinance. Wholesale of agricultural products could, with the help of legal regulations, be brought to a higher level, engaging local producers in both countries (Scott, 2020). Respondents claim that rural infrastructure is underdeveloped $(\mathrm{m}=1.60, \mathrm{sd}=0.791)$. The values of the arithmetic mean for the same question in the Republic of Srpska are $m=1.33$. Some authors emphasize that overcoming the relative backwardness of the agrarian areas of the Republic of Serbia can be achieved by proactively acting on internal and external challenges (Gajić et al., 2020). Namely, in order to achieve adequate valorization of territorial capital of agricultural areas, and increase their attractiveness, it is necessary to identify key development models, and designed and cost-effective development projects such as equipping villages with modern infrastructure and increasing profitability of agriculture and other rural activities.

Economic development and production dynamics depend on the introduction and dissemination of innovations and knowledge, which encourage the transformation and renewal of the local production system, and the creation of a recognizable brand (Quevedo-Leon et al., 2020). Creating a brand with agricultural products is of great importance, but in both countries it is rather poorly quoted, and in both countries the value of the average rating is $\mathrm{m}=1.53$. Modern technology and new trends require a change in the position of domestic agricultural producers in the market, which implies changes, ie the acceptance of modern concepts and content of quality in the formulation of business portfolios of these manufacturers Product quality standards 
were rated slightly better in Republic of Serbia $\mathrm{m}=1.79$, while in Republic of Srpska $\mathrm{m}=1.53$ ). The importance of education and knowledge transfer, as well as awareness development plays a key role in the development of rural areas. The average score for this item in Serbia is $m=1.51$, while in Republic of Srpska it is $m=1.79$. Education and knowledge transfer to farmers is the only possible way to develop their farms and improve production, and most of the responsibility for knowledge transfer lies with advisory services whose experts have a mission to reach every farmer who needs their help. Great importance in rural development would be contributed by more significant development of cooperatives and associations, which is shown by data whose grades are close to grade 2 . The association of farmers as a model of sustainable rural development is a significant factor in the accelerated development of agriculture and improving the position of agricultural producers. The advantages of the association are numerous, and among them are the facilitated procurement of raw materials and safer distribution of end products to consumers. Also, investments are significant, which shows the average grades: Republic of Serbia $m=1.62$, Republic of Srpska $m=1,70$. Numerous authors list the advantages of the association as the facilitation of the development of brands, the standardization of production, the facilitation of obtaining certificates confirming the quality of a product, and access to more favorable sources of credit. Retaining youth in rural areas would contribute to further development. Young people are an important generator of change and initiator of development, they represent a resource with many possibilities and potential that brings social change Respondents claim that it is of great importance to take all measures to stimulate youth and return to rural areas. Each of the respondents had the same answer that agriculture is crucial for the development of rural areas, which confirmed hypothesis $\mathrm{H} 2$.

Starting from the fact that the pairs have a normal distribution, testing the values of the arithmetic means of two large samples and testing the hypotheses, the t- test of paired samples was applied.

Table 4. $\mathrm{T}$ - test of statistical significance of differences in arithmetic mean of pairs $(\mathrm{df}=214)$

\begin{tabular}{|c|c|c|c|c|c|c|}
\hline \multirow{2}{*}{ Pairs } & \multirow{2}{*}{$\mathbf{r}$} & \multirow{2}{*}{$\mathbf{m}_{\mathrm{p}}$} & \multirow{2}{*}{$\mathbf{t}$} & \multirow{2}{*}{ p } & \multicolumn{2}{|c|}{$C I=95 \%$} \\
\hline & & & & & Lower & Upper \\
\hline Pair 1 & 0,136 & 0,335 & 4,866 & 0,000 & 0,199 & 0,471 \\
\hline Pair 2 & 0,222 & 0,279 & 4,422 & 0,000 & 0,155 & 0,403 \\
\hline Pair 3 & 0,301 & 0,251 & 4,422 & 0,000 & 0,117 & 0,386 \\
\hline Pair 4 & 0,082 & 0,274 & 3,500 & 0,001 & 0,429 & 0,120 \\
\hline Pair 5 & 0,475 & 0,088 & 1,680 & 0,094 & 0,192 & 0,015 \\
\hline Pair 6 & 0,136 & 0,355 & 4,866 & 0,000 & 0,199 & 0,471 \\
\hline Pair 7 & 0,222 & 0,279 & 4,422 & 0,000 & 0,155 & 0,403 \\
\hline Pair 8 & 0,301 & 0,251 & 3,679 & 0,000 & 0,117 & 0,386 \\
\hline Pair 9 & 0,082 & 0,274 & 3,500 & $\mathrm{O}, 001$ & 0,429 & 0,120 \\
\hline Pair 10 & 0,475 & 0,088 & 1,680 & 0,094 & 0,192 & 0,015 \\
\hline
\end{tabular}

$* \mathrm{r}=$ Pearson correlation, $\mathrm{mp}=$ arithmetic means of pairs, $\mathrm{p}=$ statistical significance, $\mathrm{CI}=$ Confidence Interval of the Difference 
Based on the results from Table 4, it is concluded that there is a statistically significant correlation of the variables that make up pair 1 . The value of $p=0.000$, while the correlation coefficient is 0.136 , which is a very weak correlation, but positive. The average score of this pair is $\mathrm{mp}=0.33$, and with a $95 \%$ confidence ratio, the following $\mathrm{t}$-test results were obtained $(\mathrm{t}=4.866 ; \mathrm{p}=0.000$; CI 95\% $(\mathrm{L}=0.199, \mathrm{U}=0.471))$. In pair two, a statistically significant difference in the values of arithmetic means $\mathrm{p}=$ 0.000 is also observed, the values of the dimension move in the same direction, because the correlation is positive, but weak. The average score of this pair is $m p=0.279$. Value $\mathrm{t}=4,422$, with $\mathrm{df}=214 ; \mathrm{Cl}=95 \%(\mathrm{~L}=0.155, \mathrm{U}=0.403)$. Pair 3 also has a statistically significant difference in arithmetic means, with a weak positive correlation. Value mp $=0.251$. With a $95 \%$ confidence factor, the value of $\mathrm{t}$ is $0.117(\mathrm{~L}=0.117, \mathrm{U}=0.386)$. Pair 4 has the following values $m p=0.274, p=0.001, r=0.08$, the correlation is so low that it is neglected. The T-test showed the following values of statistical significance of differences in arithmetic means: $\mathrm{t}=3,500 ; \mathrm{CI}=95 \%, \mathrm{~L}=0.429, \mathrm{U}=0.120$. The variables of pair 5 correlate weakly, but in the same direction, with $\mathrm{p}=0.09$, which is not a significant value of the statistically significant difference of the variables that make up pair $5(\mathrm{mp}=0.088 ; \mathrm{t}=1.680 ; \mathrm{CI}=95 \%, \mathrm{~L}=0.192, \mathrm{U}=\mathrm{O}, 15)$. Other pairs show statistically significant differences in arithmetic values, but a weak correlation. Par 6 shows statistical significance $\mathrm{p}=0.000$, with an average score $\mathrm{mp}=0.335(\mathrm{t}$ $=4.866 ; \mathrm{CI}=95 \% ; 1=0.199, \mathrm{U}=0.471)$. Pair 7 carries the average value of the arithmetic mean $\mathrm{mp}=0.279(\mathrm{p}=0.000 ; \mathrm{t}=4.422 ; \mathrm{CI}=95 \% ; \mathrm{L}=0.155, \mathrm{U}=0.403)$. Pair 8 has the following values: $\mathrm{mp}=0.251, \mathrm{p}=0.000, \mathrm{r}=0.3$, which is still a weak correlation. The value of $\mathrm{t}$ is $3,679(\mathrm{CI}=95 \%, \mathrm{~L}=0.117, \mathrm{U}=0.386)$. Pair 9 also shows statistical significance $\mathrm{p}=0.001$, with an average score of $\mathrm{mp}=0.274$. With a $95 \%$ confidence factor, the value of $t$ is $3,500(\mathrm{~L}=0.429, \mathrm{U}=0.120)$. A pair of ten carries an average score of $\mathrm{mp}=0.088$, and no statistics on the significance of arithmetic means and a value of $t=1.680$. The obtained data indicate the confirmation of the alternative hypothesis that there is a statistically significant difference between certain categories of agricultural development between Serbia and Republika Srpska.

\section{Conclusions}

Based on the research to determine whether there is a statistically significant difference between certain categories of agricultural development between the Republic of Serbia and the Republic of Srpska, in the function of rural development, average grades and standard deviations for given variables were established, and the hypothesis that agriculture is crucial for rural development was confirmed analyzed areas. With the help of t-test for paired samples, it was determined that there is a statistically significant difference in the arithmetic values of the given dimensions of the research. An alternative hypothesis was confirmed. The weakest marks were the dimensions of product collection, followed by providing quality standards, rural infrastructure, as well as brand development and support for young people to return or stay in rural areas where their primary activity would be agricultural production. 
The results indicate a lower level of activity of advisory bodies in the development of agricultural production, as well as the overall rural development in the Republic of Srpska in relation to the Republic of Serbia. Respondents in Serbia are more satisfied with the sale and collection of agricultural products and in general the foreign trade exchange of the mentioned products. Creating a brand of agricultural products in both countries is at a pretty bad level. Product quality standards are rated slightly better in Serbia than in the Republic of Srpska. However, the importance of education and knowledge transfer is better assessed in Republic of Srpska compared to Serbia. The results show that more significant development of cooperatives and associations would contribute to more successful development of rural areas. The analysis also shows that investments are significant in both countries.

Local communities certainly have a role to play, but the question remains whether local community support can be greater for the sector, as well as whether solutions may be in attracting more investors or joint action in terms of public-private partnership in agricultural production. The issue of rural economic development and a more holistic approach to its organization is essential for countries such as Republic of Srpska and Serbia. First of all, because it can be a significant source of competitiveness of the national economy, and we can argue that this area deserves additional attention, additional investment, as well as additional research.

\section{Conflict of interests}

The authors declare no conflict of interest.

\section{References}

1. Andrei, J. V., Mieila, M., \& Panait, M. (2017). The impact and determinants of the energy paradigm on economic growth in European Union. PloS one, 12(3), e0173282.

2. Andrei, J. V., Popescu, G. H., Nica, E., \& Chivu, L. (2020). The impact of agricultural performance on foreign trade concentration and competitiveness: empirical evidence from Romanian agriculture. Journal of Business Economics and Management, 21(2), 317-343.

3. Anríquez, A \& Stamoulis, K (2007). Rural Development and Poverty Reduction: Is Agriculture Still the Key?.ESA Working Paper No. 07-02, The Food and Agriculture Organization of the United Nations

4. Atanasoaie (2011). Distribution channels on the organic foods market. Journal of Horticulture, Forestry and Biotechnology, 15(3), 19-25.

5. Arce, A. (2003). Value contestations in development interventions: community development and sustainable livelihoods approaches. Community Development Journal, 38(3), 199-212. 
6. Bakić, S. (2020). The role of the Central Bank as a participant in the financial derivatives market. Oditor - časopis za menadžment, finansije i pravo, 6(1), 22-37. https://doi.org/10.5937/Oditor2001021B

7. Baquedano F.G., Liefert W.M., \& Shapouri S. (2011). World market integration for export and food crops in developing countries: a case study for Mali and Nicaragua. Agricultural Economics, 42, 619-630.

8. Bogdanov, N. (2007). Small rural households in Serbia and rural non-agricultural economy,UNDP, Belgrade.

9. Boyd, E. (2008). Resilience and 'climatising' development: examples and policy implications. Development, 51(3), 390-396.

10. Broad, R. (2006). Research, knowledge, and the art of 'paradigm maintenance': the World Bank's development economics vice-presidency (DEC). Review of International Political Economy, 13(3), 387-419.

11. Chivu, L., Ciutacu, C., \& Georgescu, L. (2015). Household income in Romania. A challenge to economic and social cohesion. Procedia Economics and Finance, 22, 398-401.

12. Cvijanović, D., Milojević, I. \& Pejanović, R. (2012). Macroeconomic Factors of Competitiveness of Serbian Economy and ICT Sector, International Journal of Sustainable Economies Management, Information Resources Management Association, No 1(1) (January-March 2012), 24-38. 5. European Commission (2007), Agriculture, Main statistics 2005-2006.

13. Cvijanović, D., \& Gajić, T. (2020a). The Level of Engagement of the Female Workforce in the Rural Tourism Development of Serbia. Journal of Tourism Leisure and Hospitality, A Hospitality, Tourism, Travel and Leisure Sciences Journal, TOLEHO, Anadolu University, Faculty of Tourism, 2(1), 36-42.

14. Cvijanović, D., \& Gajić, T. (2020b). Rural Resource as a Tourist Attractor. V International Conference Tourism in the Function of Rural Development of the Republic of Serbia, 4-6 jun, Vrnjacka Banja

15. Done, I., Chivu, L., Andrei, J., \& Matei, M. (2012). Using labor force and green investments in valuing the Romanian agriculture potential. Journal of Food Agriculture \& Environment, 10(3-4), 737-741.

16. De Haan, L. \& Zoomers, A. (2005). Exploring the frontier of livelihoods research. Development and Change, 36(1), 27-47.

17. Development Strategy of The Republic of Serbia, 2014.

18. Domanović, V., Vujičić, M., \& Ristić, L. (2018), Profitability of food industry companies in the Republic of Serbia. Economic of Agriculture, 65(1), 11-32.

19. Folke, C. (2002). Resilience and sustainable development: building adaptive capacity in a world of transformations. AMBIO: A Journal of the Human Environment, 31(5), 437-40. 
20. Gajic, T., Radovanovic, M., Tretiakova, T. \& Syromiatnikova, J. (2020). Creating brand confidence to gastronomic consumers through social networks - a report from Novi Sad", Journal of Place Management and Development.

21. Gajić, T., Vujko, A., Penić, M., Petrović, M. \& Mrkša, M. (2017). Significant involvement of agricultural holdings in rural tourism development in Serbia. Ekonomika poljoprivrede, 64(3), 901-919. doi: https://doi.org/10.5937/ekoPolj1703901G

22. Geels, F. \& Schot, J. (2007). Typology of sociotechnical transition pathways. Research Policy, 36(3), 399-417.

23. Hecht, A. A., Biehl, E., Barnett, D. J., \& Neff, R. A. (2019). Urban food supply chain resilience for crises threatening food security: A qualitative study. Journal of the Academy of Nutrition and Dietetics, 119(2), 211-224.

24. Jasur Hasanov., \& Haliyana Khalid (2015). The impact of website quality on online purchase intention of organic food in Malaysia: A webqual model approach. Elsevier.

25. Lemos, M. (2007). Adapting development and developing adaptation. Ecology and Society, 12(2), 26.

26. Nica, E., Sima, V., Gheorghe, I., \& Drugau-Constantin, A. (2018). Analysis of Regional Disparities in Romania from an Entrepreneurial Perspective. Sustainability, 10(10), 3450.

27. Njegovan, Z. \& Pejanović, R. (2009). Rural regionalization of AP Vojvodina, Monograph, Faculty of Agriculture, Novi Sad.

28. Ogidefa, I.S. (2010). Democracy and Good Governance: Nigeria's Dilemma. African Journal of Political Science and International Relations, 4(6), 201-208.

29. Paraušić, V. \& Cvijanović, D. (2007). Agriculture of Serbia - Financial support programs of the state and commercial banks in the period from 2004 to 2006, Institute of Agricultural Economics, Belgrade.

30. Pender, J. (2004). Development pathways for hillsides and highlands: some lessons from Central America and East Africa. Food Policy, 29(4), 339-367

31. Pillay, M., \& Rogerson, C.M. (2013). Agriculture-tourism linkages and pro-poor impacts: The accommodation sector of urban coastal KwaZulu-Natal, South Africa. Applied Geography, 36, 49-58.

32. Pradhan, M. (2015). E-agriculture: A golden opportunity for Indian farmers. International Journal of Research and Development - A Management Review, 4(1), 2319-5479.

33. Robert. J. Cox (2001). Could E-marketing be utilized in the Tasmanian organic growers industry. University of Tasmania, 15.

34. Quevedo-Leon, ' R., Bastías-Montes, J. M., Espinoza-Tellez, T., Ronceros, B., Balic, I., \& Munoz, O. (2020). Inactivation of coronaviruses in food industry: The use of inorganic and organic disinfectants, ozone, and UV radiation. Scientia Agropecuaria, 11(2), 257-266. 
35. Scoones, I. (2007). Sustainability. Development in Practice, 17(4), 589-96

36. Shiru, J.J (2008). Agricultural Mechanisation for Rural Development. Bida Journal of Management and Technology, 1(1).

37. Smith, A. (2006). Green niches in sustainable development: the case of organic food in the United Kingdom. Environment and Planning C: Government and Policy, 24(3), 439-458.

38. Stewart Lockie, K., \& Lyons G. Lawrence (2006). Going organic: Mobilizing networks for environmentally responsible food production. CABI, $126-128$.

39. Trivelli, C., \& Berdegué, JA.(2019). Transformación rural: Pensando el futuro de América Latina y el Caribe (online). Santiago, Chile, FAO. 80 p. Consulted on 13 Sept. 2019.

40. Varun Kumar, M., \& Pulidindi Venugopal (2016). E-agriculture and rural development (A study specially focused on rural farmers of Katpadi Taluk in Vellore District of Tamil Nadu). Journal of Chemical and Pharmaceutical Sciences, 9(4).

41. Winder, N; Faret, P. (2019). Garantías mínimas de protección social para el desarrollo incluyente de la economía rural en América Latina y el Caribe. Santiago, Chile, FAO. 43 p. (Serie 2030 - Alimentación, agricultura y desarrollo rural en América Latina y el Caribe, No. 22) 